\title{
STUDY OF VARIATION OF TOCOCHROMANOL AND PHYTOSTEROL CONTENTS IN BLACK AND YELLOW SEEDS OF BRASSICA NAPUS L. DOUBLED HAPLOID POPULATIONS*
}

\author{
Teresa Cegielska-Taras ${ }^{1 凶}$, Małgorzata Nogala-Kałucka², Laurencja Szala ${ }^{1}$, \\ Aleksander Siger ${ }^{2}$
}

'Plant Breeding and Acclimatization Institute - Research Division Poznań, Department of Genetics and Breeding of Oilseed Crops, Strzeszyńska 36, 60-479 Poznań, Poland

${ }^{2}$ Department of Food Biochemistry and Analysis, Poznań University of Life Sciences

Wojska Polskiego 28, 60-637 Poznań, Poland

\begin{abstract}
Background. In the study, an analysis of tocopherols, plastochomanol-8 and phytosterols was conducted using DH lines obtained from F1 hybrids of reciprocal crosses between yellow- and black-seeded lines.

Material and methods. The biological material for the study consisted of two DH populations of winter oilseed rape obtained from F1 hybrids of reciprocal crosses between two DH lines: yellow- and black-seeded. Seed color was determined using a ColorFlex spectrophotometer. Fat content was determined via pulsed NMR. The levels of tocopherols, and plastochromanol-8 are analyzed using HPLC. Phytosterol contents and composition were determined by the GC method.

Results. The fat content of the black-seeded parental line was $49 \%$ and this was higher than that of the yellow-seeded parental line (44\%). The fat content of DH line populations ranged from 44 to $51 \%$. Total tocopherol content ranged from 460 to $602 \mathrm{mg} / \mathrm{kg}$ and the $\alpha-\mathrm{T} / \gamma-\mathrm{T}$ ratio was from 0.66 to 1.09 . In parental lines $\mathrm{H}_{2}-26$ and Z-114 the total tocopherol content was 534 and $525 \mathrm{mg} / \mathrm{kg}$, but the $\alpha-\mathrm{T} / \gamma$-T ratios were 0.81 and 1.21 , respectively. The yellow-seeded parental line (Z-114) was characterized by a higher PC-8 content $(81 \mathrm{mg} / \mathrm{kg})$ than the $\mathrm{H}_{2}-26$ black-seeded parental line $(58 \mathrm{mg} / \mathrm{kg})$. The largest part of the total phytosterol content in seeds of both populations was $\beta$-sitosterol from 976 to $2148 \mathrm{mg} / \mathrm{kg}$, followed by campasterol, from 636 to $1364 \mathrm{mg} / \mathrm{kg}$, and brassicasterol from 375 to $678 \mathrm{mg} / \mathrm{kg}$. The total tocopherol content ranged from 462 to $595 \mathrm{mg} / \mathrm{kg}$ (population HxZ) and from 460 to $602 \mathrm{mg} / \mathrm{kg}$ (population ZxH). Significantly positive correlations were observed between the seed color with $\alpha$-T $(r=0.38, p<0.01), \gamma$-T $(r=-0,34, p<0.01)$ and PC-8 content $(r=0.29, p<0.01)$. Correlations between the seed color with total tocopherol and total phytosterol content were not noted.

Conclusion. Considering the range of genetic variation among doubled haploids of two populations, selected DH lines may be good parents for further breeding programs focused on increasing the amount and improving the quality of oilseed rapeseed oil. However, further studies will also be made to determine the influence of the environment on bioactive compounds in rapeseed oil. Cross direction of parental DH lines: yellow- and black-seeded has some influence, albeit not statistically significant, on the diversity of doubled haploid in their populations with regard to average fat, tocochromanol and phytosterol content.
\end{abstract}

Key words: Brassica napus L., oilseed rape, doubled haploid, black and yellow seeds, tocopherols, phytosterols

\footnotetext{
* This work was partially supported by the Polish Ministry of Agriculture and Rural Development Task 2.7/2015 project. 


\begin{abstract}
Abbreviations: DH - doubled haploid, $\alpha-\mathrm{T}-$ alpha tocopherol, $\beta-\mathrm{T}-$ beta tocopherol, $\gamma-\mathrm{T}-$ gamma tocopherol, $\delta$-T - delta tocopherol, PC-8 - plastochromanol- $8, \mathrm{H} \times \mathrm{Z}$ - black-seeded $\times$ yellow-seeded $\mathrm{DH}$ line population, $\mathrm{Z} \times \mathrm{H}-$ yellow seeded $\times$ black seeded DH line population.
\end{abstract}

\section{INTRODUCTION}

Recently, nutraceuticals, ie. food products ensuring prophylactic and therapeutical action through biologically active substances, have gained in popularity. They contain substances which are exogenic to human organisms and can only be synthesized by plants, particularly by oilseed ones. The main representatives of such constituent are native antioxidants - tocochromanols: tocopherols, tocotrienols, which are vitaminE active compounds and plastochromanol-8, phytosterols, as well as $\beta$-carotene and phenolic compounds. In the green parts of plants and in the seeds of oilseed rape four homologues have been found $\alpha-, \beta-, \gamma$ and $\delta$-tocopherol $(-\mathrm{T})$. The main dominant forms are $\alpha-$ and $\gamma$-T, while $\delta$-T occurred in small amounts and $\beta$-T in trace (Goffman and Becker, 2001; Marwede et al., 2004; Nogala-Kałucka et al., 2005). The ratio of $\alpha$-T to $\gamma$-T between 0.54-1.70 (Marwede et al., 2004). Furthermore, plastochromanol-8 (PC-8), belonging to a non-glycerol substance, occurs with tocopherols. The compound belongs to the tocopherol-like group, which demonstrate antioxidant properties (MèneSaffrané and DellaPenna, 2010). Rapeseed oil is a very valuable source of natural bioactive components which contribute to the quenching of free radicals during metabolic processes. They are the main factor for maintaining cell membranes in their proper structure and permeability. All tocochromanols are potent lipid soluble antioxidants and, like vitamin E, are essential dietary nutrients for mammals (Mène-Saffrané and DellaPenna, 2010). All these native antioxidants, and phytosterols too, are natural nutritive compounds (Hamama et al., 2003; Wittkop et al., 2009), due to their anticholesterolemic properties. Phytosterol are found in a free form or in ester-bound forms with fatty acids or certain phenolic acids (Gül and Amar, 2006; Wąsowicz and Rudzińska, 2010). The biological activity of phytosterols consists mainly in their capacity to reduce the blood cholesterol level by competing with cholesterol during absorption (Gül and Amar, 2006). Phytosterol also exhibit antipolimerisation properties during frying (Blekas and Boskou, 1999). Their presence in seeds determines the nutritive value of oil - refined but mainly cold-pressed (Matthäus, 2012; Siger et al., 2015). Enhancing its bioactive constituent, such as its tocochromanol and phytosterol content, has become an important objective in oilseed breeding (Amar et al., 2008a; Dörmann, 2007; Goffman and Becker, 2001; Goffman and Möllers, 2000).

Oilseed rape is a valuable raw material for the production of oil, while by-products like meal or cake may be used as a good high-protein feed. Hence we observe an increasing trend in oilseed rape production. The importance of rapeseed in the economy results in many research programs aimed at improving this plant. Until now research has led to a substantial increase in the fertility of varieties. A double zero cultivar of oilseed rape with a reduced amount of erucic acid $(<2 \%)$ and reduced glucosinolate content have also been developed bred (Booth and Gunstone, 2004; Eskin, 2013). Varieties which are beneficial to health through their level of special fatty acids content in oil (Friedt and Snowdon, 2009). Breeding of cultivars with a high native bioactive compound content (tocochromanols, phytosterols) is performed continuously. Many authors present the results of genotype $x$ environment interactions on the level of tocopherols, fatty acids, phytoserols or sinapate ester in Brassica napus (Amar et al., 2008a; Marwede et al., 2004; Marwede et al., 2005; Wang et al., 2012; Zhang et al., 2004; Zhao et al., 2008). However, the majority of this research concerns black-seeded Brasica napus. Since the 1980s research programs concerning yellowseeded rapeseed with a reduced dietary fiber content and high level of fat and protein have been run (Meng et al., 1998; Rahman and McVetty, 2011; Rashid et al., 1994; Relf-Eckstein et al., 2003). This paper studies the variability of the tocochromanol and phytosterol content in rapeseed breeding lines obtained by reciprocal crossing of black-seeded and yellow-seeded parental lines. The search for genetic variability of tocochromanol, phytosterol and fat content was initiated in two populations of doubled haploid lines (DH), which are particularly useful for rare genotype selection, because of the simplified genetics in the haploid system. 


\section{MATERIALS AND METHODS}

\section{Chemicals}

$5 \alpha$-cholestane was purchased from Sigma (St. Louis, MO). All tocopherol homologues (purity $>95 \%$ by HPLC) were obtained from Calbiochem-Merck Biosciences (Darmstadt, Germany). n-Hexane (HPLC-grade), and 1.4-dioxane (HPLC-grade) were purchased from Merck (Darmstadt, Germany). All other solvents and chemicals used in this study were of analytical grade.

\section{Materials}

The biological material for the study consisted of two populations of doubled haploids of winter oilseed rape obtained from F1 hybrids of reciprocal crosses between two DH lines: yellow and black seeds. These DH lines were chosen from two populations which were obtained by using an in vitro culture of isolated microspores (Cegielska-Taras et al., 2002). In the study, a $\mathrm{H} \times \mathrm{Z}$ population of doubled haploids was developed from $F 1$ hybrids obtained from the cross of DH $\mathrm{H}_{2} 26$ (black seeds) $\times$ DH Z114 (yellow seeds) and consisted of $27 \mathrm{DH}$ lines. The second population of doubled haploids $(\mathrm{Z} \times \mathrm{H})$ was developed from an $\mathrm{F} 1$ hybrid obtained from a cross between DH Z114 (yellow seeds) $\times \mathrm{DH} \mathrm{H}_{2} 26$ (black seeds) and consisted of $36 \mathrm{DH}$ lines. A study of bioactive compounds in seeds was conducted on plants grown in field trials. Field trials were carried out in Lagiewniki, Poland in the 2008/09 growing seasons on plots of $4.5 \mathrm{~m} \times 1.2 \mathrm{~m}$ (length $\times$ width).

\section{Seeds color}

Seed color was determined using a ColorFlex spectrophotometer on a scale from 0 (black) to 5 (yellow) (Michalski, 2009).

\section{Fat content}

Fat content in seeds was determined via nuclear magnetic resonance (NMR), in accordance with Michalski's method (2005).

\section{Tocochromanol and plastochromanol-8 contents}

Samples of seeds $(2 \mathrm{~g})$ were saponified using $60 \%$ $\mathrm{KOH}(2 \mathrm{~mL})$, ethanol $(20 \mathrm{~mL})$ and pyrogallol $(0.5 \mathrm{~g})$. Saponification was carried out at the ethanol boiling point temperature $\left(78^{\circ} \mathrm{C}\right)$ for $30 \mathrm{~min}$. After saponification, unsaponifiable substances were extracted using $50 \mathrm{~mL} n$-hexane/ethyl acetate $(90: 10 \mathrm{v} / \mathrm{v}) .100 \mu \mathrm{L}$ of the organic layer (unsaponifiable) were collected for high-performance liquid chromatography (Waters 600 Milford, MA, USA). A LiChrosorb Si60 column $(250 \times 4.6 \mathrm{~mm} ; 5 \mu \mathrm{m})$ and a LiChrospher Si60 precolumn were used. The mobile phase consisted of $n$ -hexane and 1,4-dioxane $(97: 3 \mathrm{v} / \mathrm{v})$. The flow rate was $1.5 \mathrm{~mL} / \mathrm{min}$. A fluorometric detector (Waters 474 Milford, MA, USA) worked at an excitation of $295 \mathrm{~nm}$ and an emission of $330 \mathrm{~nm}$ (Gawrysiak-Witulska et al., 2011). Tocopherols $(\alpha-\mathrm{T}, \beta-\mathrm{T}, \boldsymbol{\gamma}-\mathrm{T}, \delta$-T) were identified by comparing retention time, and concentrations were calculated through a comparison of the area values with values from exterior standard tocopherols.

\section{Phytosterol content}

Phytosterol content were determined by the AOCS Official Method with modification by (Ciftci et al., 2011). In brief, extracted oils (50 mg) were saponified with $1 \mathrm{M} \mathrm{KOH}$ in methanol for $18 \mathrm{~h}$ at room temperature, then water was added and unsaponifiables were extracted three times with hexane/methyl tert butyl ether $(1: 1, \mathrm{v} / \mathrm{v})$. The solvent was evaporated under a stream of nitrogen. Dry residues were dissolved in $0.2 \mathrm{~mL}$ pyridine and silylated with $0.8 \mathrm{~mL}$ of Sylon BTZ (Supelco, Bellefonte, PA, USA). Derivatives of the phytosterols were separated on a gas chromatograph HP 6890 equipped with a DB-35MS capillary column $(25 \mathrm{~m} \times 0.20 \mathrm{~mm} ; 0.33 \mu \mathrm{m}$; J\&W Scientific, Folsom, CA). A sample was injected in a splitless mode. Column temperature was held at $100^{\circ} \mathrm{C}$ for $5 \mathrm{~min}$, then programmed to $250^{\circ} \mathrm{C}$ at $25^{\circ} \mathrm{C} \mathrm{min}{ }^{-1}$, held for $1 \mathrm{~min}$, then further programmed to $290^{\circ} \mathrm{C}$ at $3^{\circ} \mathrm{C}$ $\mathrm{min}^{-1}$ and held for $20 \mathrm{~min}$. Detector temperature was set at $300^{\circ} \mathrm{C}$. Hydrogen was used as a carrier gas at a flow rate of $1.5 \mathrm{~mL} \mathrm{~min}^{-1}$. As an internal standard $5 \alpha$-cholestane was used for phytosterol quantification. Phytosterols were identified by comparing retention data of standards and the identity was confirmed using an Agilent Technologies 7890A GC coupled to a 5975C VL MSD Triple-Axis Detector after separation on a DB-5 capillary column $(30 \mathrm{~m} \times 0.2 \mathrm{~mm}$, $0.32 \mathrm{~mm}$; J\&W). Helium was used as a carrier gas at a flow rate of $0.6 \mathrm{~mL} \mathrm{~min}{ }^{-1}$. All mass spectra were recorded using the electron-impact ionization mode at 
$70 \mathrm{eV}$ and scanning mass in the range of 100-650 Da. The ion source was held at $200^{\circ} \mathrm{C}$ and the injector at $300^{\circ} \mathrm{C}$. A combination of the NIST Mass Spectra Library and a laboratory sterol spectra library were used for identification.

\section{Statistical analysis}

The results are presented as minimum, maximum and coefficient of variability from three replicates of each experiment. The relationship between the variables was assessed using Pearson's correlation coefficient. Its significance was evaluated with Student's t-test. Intra-sample quantity variation of oils sampled was assayed using the Principal Component Analysis (PCA). All tests were considered significant at $p<0.05$. Statistical analysis was performed using the Statistica 10.0 software (StatSoft, Inc., Tulsa, OK).

\section{RESULTS AND DISCUSSION}

\section{Color measurement and fat content}

In the process of androgenesis in vitro of $\mathrm{F}_{1}$ hybrids derived from reciprocal crosses of DH lines: blackand yellow-seeded obtained two populations of doubled haploid $\mathrm{H} \times \mathrm{Z}-27$ lines and $\mathrm{Z} \times \mathrm{H}-36$ lines. The color seeds of these populations varied from black through brown to yellow. The lines were then divided according to seed color from scale $0-5$ of black-yellow respectively (Table 1). Six DH lines in the population $\mathrm{H} \times \mathrm{Z}$ and 15 in the $\mathrm{Z} \times \mathrm{H}$ population had a black color, while yellow was the seed coat color of $7 \mathrm{DH}$ lines in the population $\mathrm{H} \times \mathrm{Z}$ and $2 \mathrm{DH}$ lines in the $\mathrm{Z} \times \mathrm{H}$ population. In the latter population $8 \mathrm{DH}$ lines were characterized by the brown color of their seed coat (2-3 colorflex scale). Black seed parental line DH $\mathrm{H}_{2} 26$ had a fat content of $49 \%$, which was higher than the yellow seed parent DH Z114 - 44\%. However, the DH lines of both populations exceed the value of the parental lines up to $\mathrm{p}$ to $51 \%$ of fat. The coefficients of variability of fat content were 4.2 and 4.7 (Table 2). Comparing the average fat content between the populations studied $(\mathrm{Z} \times \mathrm{H} v s . \mathrm{H} \times \mathrm{Z})$ revealed no statistically significant difference ( $p=0.476$ ) (Fig. 1).

Black oilseed rape is commonly grown and there is ongoing work to improve it. To this day, its yield has

Table 2. Range of fat content in two populations of doubled haploid lines and parental line: $\mathrm{DH} \mathrm{H}_{2} 26$ and DH Z-114

\begin{tabular}{lc}
\hline & Fat content, \% \\
\hline $\mathrm{H} \times \mathrm{Z}$ (black $\times$ yellow) population $-27 \mathrm{DHs}$ \\
Minimum & 44.1 \\
Maximum & 51.2 \\
Coefficient of variability & 4.2 \\
$\mathrm{Z} \times \mathrm{H}$ (yellow $\times$ black) population $-36 \mathrm{DHs}$ \\
Minimum & 43.8 \\
Maximum & 50.9 \\
Coefficient of variability & 4.7 \\
Parental lines & \\
DH H 26 - black seed & 49.4 \\
DH Z-114 — yellow seed & 44.4 \\
\hline
\end{tabular}

Table 1. Seed color in two populations of doubled haploid lines and parental lines: $\mathrm{DH} \mathrm{H}_{2} 26$ and DH Z-114 (colorflex scale)

\begin{tabular}{lccccc}
\hline & $\begin{array}{c}0-1 \\
\text { black color }\end{array}$ & $1-2$ & $2-3$ & $3-4$ & $\begin{array}{c}4-5 \\
\text { yellow color }\end{array}$ \\
\hline $\mathrm{H} \times \mathrm{Z}$ (black $\times$ yellow) population $-27 \mathrm{DHs}$ & 9 & 3 & 4 & 4 & 7 \\
$\mathrm{Z} \times \mathrm{H}$ (yellow $\times$ black) population $-36 \mathrm{DHs}$ & 15 & 4 & 8 & 7 & 2 \\
Parental lines & & & & \\
$\mathrm{DH} \mathrm{H}$ & 26 - black seed & & & $\mathrm{X}$ \\
$\mathrm{DH} \mathrm{Z}-114-$ yellow seed & & & \\
\hline
\end{tabular}


been improved and double low cultivars have been developed and introduced into production. Currently, work is being done on increasing the amount of active biological compounds such as phytosterols and tocopherols (Eskin, 2013; Fritsche et al., 2012; Marwede et al., 2005; Marwede et al., 2004; Siger et al., 2015). Studies of yellow-seeded oilseed rape are being conducted with the aim of decreasing the dietary fiber content of the seeds, while increasing their oil and protein contents (Rahman and McVetty, 2011; Rashid et al., 1994). Using a broad range of genotypes including black-, brownand yellow-seeded DH lines, we analyzed the content of lipid soluble secondary compounds: tocochromanols (e.g. tocopherols and PC-8) and phytosterols, determining the oxidative stability of the oil and also their essential function in nutrition.

\section{Tocopherol and PC-8 content}

The total tocopherol content for the doubled haploids of the two populations ranged from c. 462 to $602 \mathrm{mg} / \mathrm{kg}$ and the $\alpha-\mathrm{T} / \gamma$-T ratio was c. from 0.66 to 1.09 (Table 3). While parental lines DH $\mathrm{H}_{2} 26$ and DH Z114 possessed total tocopherol contents of 534 and $525 \mathrm{mg} / \mathrm{kg}$, the $\alpha-\mathrm{T} / \gamma-\mathrm{T}$ ratio ranged from 0.81 to 1.21 , respectively
(Table 3). The highest $\alpha$-T content $(296 \mathrm{mg} / \mathrm{kg}$ ) was observed in the $\mathrm{Z} \times \mathrm{H}$ population, while the highest $\gamma$ - $\mathrm{T}$ content $(354 \mathrm{mg} / \mathrm{kg}$ ) was seen in the $\mathrm{H} \times \mathrm{Z}$ population. The black-seeded parental line $\mathrm{DH} \mathrm{H}_{2} 26$ possessed 236 $\mathrm{mg} / \mathrm{kg} \alpha-\mathrm{T}$ and about $292 \mathrm{mg} / \mathrm{kg} \gamma$-T content in the oil. The yellow-seeded parental line DH Z114 contained approximately $283 \mathrm{mg} / \mathrm{kg} \alpha-\mathrm{T}$ and $235 \mathrm{mg} / \mathrm{kg} \gamma-\mathrm{T}$ in the total amount of these bioactive compounds in the oil. Among the doubled haploids of the populations tested, plastochromanol-8 content ranged from 48.4 to $98.0 \mathrm{mg} / \mathrm{kg}$. The highest amount of PC-8 was in seeds from the $\mathrm{DH}$ line from the $\mathrm{Z} \times \mathrm{H}$ population. The yellow-seeded parental line was characterized by a higher PC-8 content $(81.4 \mathrm{mg} / \mathrm{kg})$ than that of the black-seeded parental line $(58.3 \mathrm{mg} / \mathrm{kg})$. The coefficients of variability were highest for $\beta$-T content $(34.2 \%$ and $52.3 \%$ for the $\mathrm{H} \times \mathrm{Z}$ and $\mathrm{Z} \times \mathrm{H}$ populations, respectively) and lowest for the total tocopherol content $(5.8 \%$ and $6.1 \%$ for $\mathrm{H} \times \mathrm{Z}$ and $\mathrm{Z} \times \mathrm{H}$ populations, respectively). For the $\alpha-\mathrm{T} / \gamma-\mathrm{T}$ ratio, a coefficient of variability of about $12 \%$ was noted. The CV value for PC-8 content was $14.1 \%$ for the $\mathrm{DH}$ lines of the $\mathrm{H} \times \mathrm{Z}$ population and $15.7 \%$ of $\mathrm{DH}$ lines from the $\mathrm{Z} \times \mathrm{H}$ population (Table 3 ). In the $\mathrm{DH}$ lines of each population great variation in the value of

Table 3. Tocochromanol content in two populations of doubled haploid lines and parental lines: $\mathrm{DH} \mathrm{H}_{2} 26$ and DH Z-114 of winter oilseed rape (Brassica napus L.), $\mathrm{mg} / \mathrm{kg}$ seed

\begin{tabular}{|c|c|c|c|c|c|c|c|}
\hline & \multicolumn{5}{|c|}{ Tocopherol content, $\mathrm{mg} / \mathrm{kg}$} & \multirow{2}{*}{$\begin{array}{c}\text { Ratio } \\
\alpha-T / \gamma-T\end{array}$} & \multirow{2}{*}{$\begin{array}{l}\text { PC- } 8 \text { con- } \\
\text { tent, } \mathrm{mg} / \mathrm{kg}\end{array}$} \\
\hline & $\alpha-\mathrm{T}$ & $\beta-\mathrm{T}$ & $\gamma-\mathrm{T}$ & $\delta$ - $\mathrm{T}$ & Total & & \\
\hline \multicolumn{8}{|c|}{$\mathrm{H} \times \mathrm{Z}$ (black $\times$ yellow) population } \\
\hline Minimum & 202 & 0.5 & 238 & 3.2 & 462 & 0.66 & 49.8 \\
\hline Maximum & 267 & 2.4 & 354 & 7.7 & 595 & 1.09 & 87.5 \\
\hline Coefficient of variability & 8.15 & 34.19 & 8.37 & 17.9 & 5.76 & 11.9 & 14.08 \\
\hline \multicolumn{8}{|c|}{$\mathrm{Z} \times \mathrm{H}$ (yellow $\times$ black) population } \\
\hline Minimum & 195 & 0.5 & 249 & 3.4 & 460 & 0.66 & 48.4 \\
\hline Maximum & 296 & 4.1 & 338 & 6.3 & 602 & 1.08 & 98.0 \\
\hline Coefficient of variability & 9.56 & 52.27 & 7.68 & 17.32 & 6.08 & 12.30 & 15.72 \\
\hline \multicolumn{8}{|l|}{ Parental lines } \\
\hline $\mathrm{DH} \mathrm{H}_{2} 26$ - black seed & 236 & 1.9 & 292 & 4.5 & 534 & 0.81 & 58.3 \\
\hline DH Z-114 — yellow seed & 283 & 1.8 & 235 & 5.6 & 525 & 1.21 & 81.4 \\
\hline
\end{tabular}


bioactive compounds studied was observed. However, there were no statistically significant differences between both populations when total tocopherol content $(p=0.245)$ and PC-8 content $(p=0.477)$ were compared (Fig. 1).

The content of these constituents in the DH lines of the two populations exceed the value of their parental lines. In Brassica napus breeding besides improving yield and yield stability and increasing the oil content, attention has recently been paid to minor seed constituents like tocochromanols (Marwede et al., 2004; Marwede et al., 2005) and phytosterols (Amar et al., 2008b). Improving the composition of bioactive compounds (e.g., tocochromanols and phytosterols) must be a major breeding aim for high-quality vegetable oil production. Plant oils rich in bioactive compounds are preferable for the preparation of functional food. Thus, oilseed rape cultivars with increased tocopherol content or with altered seed tocopherol composition are sought. It has previously been shown that total phytosterol and tocochromanol content is affected by genetic control (Abidi et al., 1999). Thus, it is possible to obtain genotypes of B. napus containing bioactive compounds that are beneficial for human health.

Using doubled haploids in breeding can increase the efficiency of the selection of homozygous lines with the desired quality characteristics. In both populations of DH lines, higher content of fat, tocopherols, PC-8, and phytosterols, which are considered beneficial in terms of economic and nutritive values, were obtained than were present in the parental lines. The genetic variation of tocopherol content and its
A

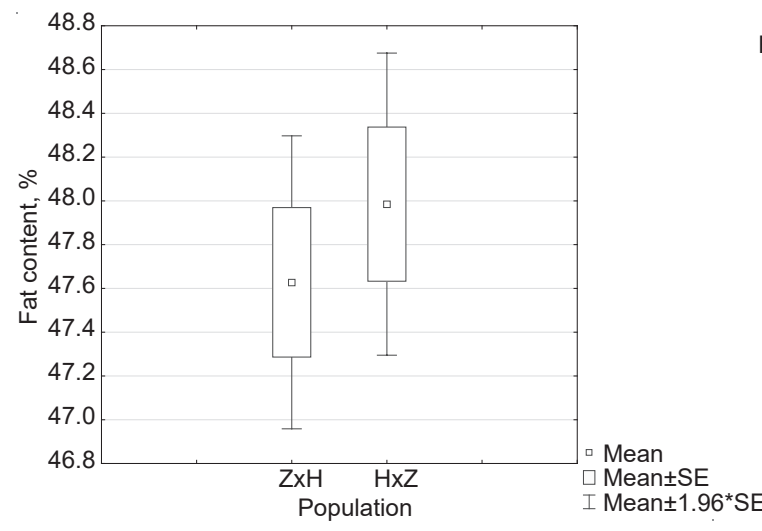

$p=0.476$

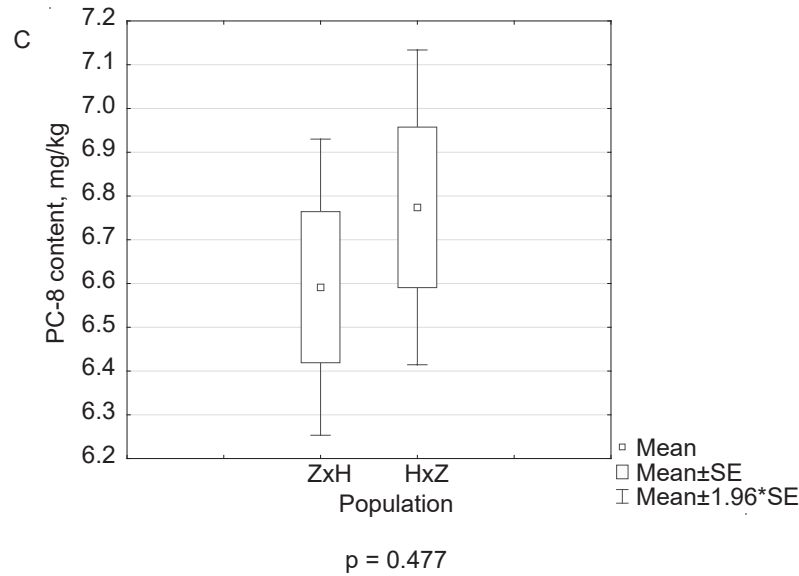

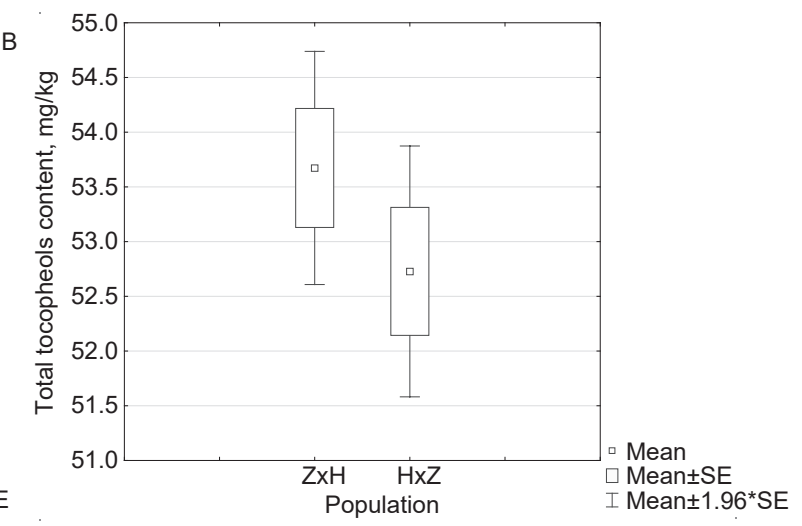

$p=0.245$

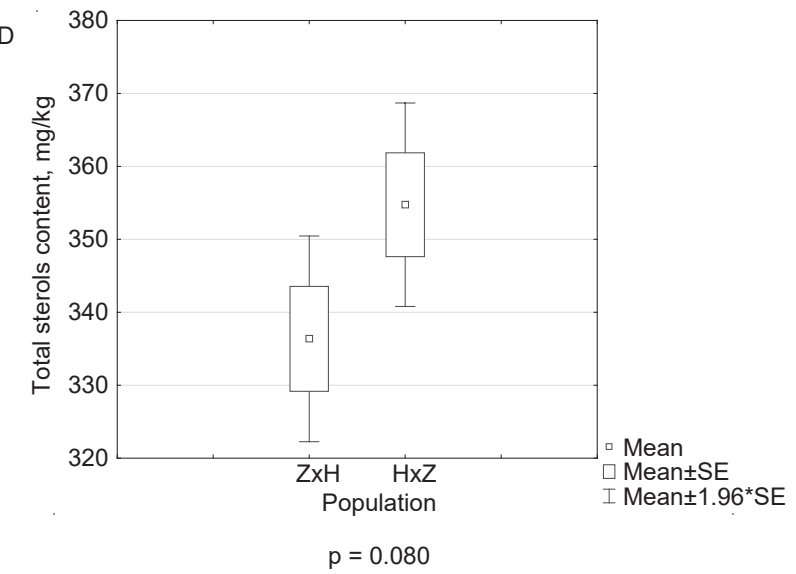

Fig. 1. Comparison of the average fat (A), total tocopherols (B), PC-8 (C) and total sterols (D) content between two populations of doubled haploid of winter oilseed rape (Brassica napus L.) 
composition in a collection of 87 oilseed rape genotypes has previously been shown (Eskin, 2013). However, this large variation in tocopherol content is partly due to environmental factors. Significant genotypic differences occur, but large genotype $\times$ environment interaction is the major source of variation (Marwede et al., 2004). The findings produced in an earlier paper showed that the environmental interaction observed with tocopherol content is a source of variation among selected DH lines, but the calculated $\alpha-\mathrm{T} / \gamma$-T ratio seemed to be stable across years and location (Siger et al., 2015). The coefficient of variability calculated for the $\alpha-\mathrm{T} / \gamma$-T ratio was about $15 \%$, which suggests the possibility of selecting desired DH lines.

The yellow-seeded parental line DH Z114 proved to be a source of high $\alpha$-tocopherol content. Consequently, a significant correlation was observed between seed color and the content of this tocopherol homologue, as well as the $\alpha-\mathrm{T} / \gamma-\mathrm{T}$ ratio. The results from this study of two populations obtained from reciprocal crosses of black- and yellow-seeded parents indicated a variation in terms of total tocopherol content and $\alpha-\mathrm{T} / \gamma-\mathrm{T}$ ratio, and especially PC- 8 content. The results of a study by Eskin (2013) reveal that yellow-seeded B. napus DH lines were characterized by a higher amount of $\alpha$-tocopherol and lower $\gamma$-tocopherol content than black seeded DH lines. The $\alpha-\mathrm{T} / \gamma$-T ratio was higher in yellow-seeded DHs compared to black-seeded lines. Siger et al. (2015) analyzed the tocochromanol content in $25 \mathrm{DH}$ lines derived from crosses between yellow- and black-seeded oilseed rape and showed that the average content of tocopherol was $46.91 \mathrm{mg} / 100 \mathrm{~g}$. The $\alpha-\mathrm{T} / \gamma-\mathrm{T}$ factor was 0.97 , which indicates that most lines contained homologue $\gamma$-T. The average PC-8 content was $6.72 \mathrm{mg} / 100 \mathrm{~g}$.

\section{Phytosterol content}

Total phytosterol content amounted to $4182 \mathrm{mg} / \mathrm{kg}$ in the DH populations analyzed, whereas parental lines $\mathrm{DH} \mathrm{H}_{2} 26$, and DH Z114 contained 3623.6 and 3417.7

Table 4. Phytosterol content in two populations of doubled haploid lines and parental lines: $\mathrm{DH} \mathrm{H}_{2} 26$ and DH Z-114 of winter oilseed rape (Brassica napus L.), $\mathrm{mg} / \mathrm{kg}$

\begin{tabular}{|c|c|c|c|c|c|c|c|c|c|c|c|}
\hline & \multicolumn{2}{|c|}{ Brassicasterol } & \multicolumn{2}{|c|}{ Campesterol } & \multicolumn{2}{|c|}{ Stigmasterol } & \multicolumn{2}{|c|}{$\beta$-Sitosterol } & \multicolumn{2}{|c|}{ Avenasterol } & \multirow{2}{*}{$\begin{array}{c}\text { Total phy- } \\
\text { tosterols } \\
\mathrm{mg} / \mathrm{kg}\end{array}$} \\
\hline & $\mathrm{mg} / \mathrm{kg}$ & $\begin{array}{l}\% \text { of } \\
\text { total }\end{array}$ & $\mathrm{mg} / \mathrm{kg}$ & $\begin{array}{l}\% \text { of } \\
\text { total }\end{array}$ & $\mathrm{mg} / \mathrm{kg}$ & $\begin{array}{l}\% \text { of } \\
\text { total }\end{array}$ & $\mathrm{mg} / \mathrm{kg}$ & $\begin{array}{l}\% \text { of } \\
\text { total }\end{array}$ & $\mathrm{mg} / \mathrm{kg}$ & $\begin{array}{l}\% \text { of } \\
\text { total }\end{array}$ & \\
\hline \multicolumn{12}{|c|}{$\mathrm{H} \times \mathrm{Z}$ (black $\times$ yellow) population } \\
\hline Minimum & 426.0 & 12.8 & 762.2 & 25.8 & 6.2 & 0.2 & 1498.8 & 51.4 & 23.6 & 0.8 & 2915.0 \\
\hline Maximum & 678.3 & 16.5 & 1332.4 & 34.2 & 126.9 & 3.3 & 2144.9 & 52.1 & 145.7 & 3.9 & 4127.5 \\
\hline $\begin{array}{l}\text { Coefficient of } \\
\text { variability }\end{array}$ & 11.57 & & 12.87 & & 95.34 & & 9.29 & & 37.67 & & 9.6 \\
\hline \multicolumn{12}{|c|}{$\mathrm{Z} \times \mathrm{H}$ (yellow $\times$ black) population } \\
\hline Minimum & 357.2 & 16.9 & 636.0 & 30.2 & 0.00 & 0.0 & 976.5 & 46.3 & 34.7 & 1.1 & 2108.7 \\
\hline Maximum & 593.1 & 15.5 & 1364.6 & 32.6 & 105.8 & 3.2 & 2148.2 & 52.3 & 169.6 & 4.8 & 4182.5 \\
\hline $\begin{array}{l}\text { Coefficient of } \\
\text { variability }\end{array}$ & 12.13 & & 16.20 & & 75.51 & & 13.31 & & 37.21 & & 12.83 \\
\hline \multicolumn{12}{|l|}{ Parental lines } \\
\hline $\begin{array}{l}\mathrm{DH} \mathrm{H}_{2} 26 \text { - black } \\
\text { seed }\end{array}$ & 498.6 & 13.8 & 1184.8 & 32.7 & 48.6 & 1.3 & 1805.7 & 49.8 & 85.9 & 2.37 & 3623.6 \\
\hline $\begin{array}{l}\text { DH Z-114 - } \\
\text { yellow seed }\end{array}$ & 529.0 & 15.5 & 881.7 & 25.8 & 9.3 & 0.3 & 1930.3 & 56.5 & 67.3 & 2.00 & 3417.7 \\
\hline
\end{tabular}


$\mathrm{mg} / \mathrm{kg}$ of these bioactive compounds, respectively (Table 4). The largest parts of the total phytosterol content in $\mathrm{DH}$ lines of both populations were $\beta$-sitosterol from 976.5 to $2148.2 \mathrm{mg} / \mathrm{kg}$, campesterol from 636.0 to $1364 \mathrm{mg} / \mathrm{kg}$ and brassicasterol from 357.2 to 678.3 $\mathrm{mg} / \mathrm{kg}$. Other phytosterols, stigmasterol and avenasterol, were represented in trace amounts. In the seeds of parental lines, there were similar amounts and types of phytosterols, except for campesterol and stigmasterol. Yellow-seeded DH Z114 was characterized by lower amounts of campesterol $(881.7 \mathrm{mg} / \mathrm{kg})$ and stigmasterol $(9.3 \mathrm{mg} / \mathrm{kg})$ than that of black-seeded $\mathrm{DH} \mathrm{H}_{2} 26$ (1184.8 and $48.6 \mathrm{mg} / \mathrm{kg}$, respectively). The coefficients of variability in two DH populations for total phytosterol were from 9.6 to $12.8 \%$ for the two major phytosterols: i.e. $\beta$-sitosterol from $9.3 \%$ to $13.3 \%$ and campesterol from 12.9 to $16.2 \%$ (Table 4).

Increasing the phytosterol content of oil could increase the value of an oilseed rape crop. High phytosterol content is found in the seeds of oilseed plants. Among these, oilseed rape has been identified as the one with the highest content (Amar et al., 2008a). In Brassica napus a large part of phytosterols comprises $\beta$-sitosterol (45-58\%) and campesterol (25-39\%), followed by brassicasterol and avenasterol, with stigmasterol occurring in small quantities (Hamama et al., 2003; Nogala-Kałucka et al., 2005). Increased phytosterol content in oilseed rape could constitute an added value to oil and its derivatives. In the two populations of winter oilseed rape studied the phytosterol content of each turned out to be higher than in the work of Hamama et al. (2003), although the corresponding compounds were all in the similar propotion. Amar et al. (2008a) reported a variation in total phytosterol content ranging from 2570 to $4150 \mathrm{mg} / \mathrm{kg}$ seed for three different doubled haploid populations of winter oilseed rape tested in field experiments.

\section{Statistical analysis}

The correlation coefficient showed a negative association between fat content and the color of the seeds. The black-seeded parental line contained more fat than the yellow DH one (Table 5). A significant positive correlation was revealed between seed color and $\alpha-\mathrm{T}(r=0.38, p<0.01)$ and PC-8 $(r=0.29$, $p<0.01)$ content, as well as yellow seeds lines being characterized by a significantly higher ratio $\alpha-\mathrm{T} / \gamma-\mathrm{T}$. The seed color was significantly negative correlated to the $\gamma$-T content $(r=-0.34, p<0.01)$. In contrast, total tocopherol and total phytosterol content were not correlated with the color of the seeds (Table 5). Marwede et al. $(2004 ; 2005)$ proved a significant correlation (0.91 and 0.92$)$ between $\gamma$-T and total tocopherol content in the DH population. (Wang et al., 2012) also showed a similar relationship between $\gamma$-T and total tocopherol content (0.91) in the TNDH population (Tapidor $\times$ Ningyou7 doubled the haploid population). Siger et al. (2015) showed a statistical significant positive relationship between $\alpha-\mathrm{T}$ and $\gamma$-T $(r=0.291, p<0.05)$ and negative relationship for $\gamma$-T and $\beta$-T $(r=-0.306, p<0.05), \gamma$-T and $\delta$-T $(r=-0.247, p<0.05)$ and $\alpha-\mathrm{T}$ and $\delta-\mathrm{T}(r=-0.025$, $p<0.05)$. PC-8 directly correlated with $\alpha-\mathrm{T}, \beta-\mathrm{T}$ and $\delta$-T $(r=0.116, r=0.249, r=0.167, p<0.05)$ and inversely with $\gamma$-T $(r=-0.242, p<0.05)$ (Siger et al., 2015). Principal Component Analysis (PCA) confirmed a variation in the DH line tested in the $\mathrm{Z} \times \mathrm{H}$ population of doubled haploid of winter oilseed rape (Brassica napus) (Fig. 2). The greatest effect on factor 1 in PCA is positively correlated with the content of brassicasterol (0.85), $\beta$-sitosterol $(0.84)$ and campesterol (0.84). In turn, factor 2 is negatively correlated with the PC- 8 content $(0.87)$ and positively correlated with the contents of $\delta$-T $(0.88)$. Lines $(\mathrm{Z} \times \mathrm{H}: 14 ; 32 ; 80)$ were characterized by a high content of tocopherol, whereas and high content of phytosterols was observed in lines $\mathrm{Z} \times \mathrm{H}: 67 ; 73 ; 75$; $76 ; 85 ; 107$. The PCA scores for the new line in the $\mathrm{H} \times \mathrm{Z}$ population of doubled haploid of winter oilseed rape are presented in Figure 3. The greatest effect on factor 1 in PCA is negatively correlated with the content of stigmasterol $(-0.89), \beta$-sitosterol $(-0.78)$, campesterol $(-0,74)$ and avenasterol $(-0.60)$. In turn, factor 2 is positively correlated with the level of $\alpha$-T (0.73) and $\mathrm{PC}-8(0.62)$. In the population $\mathrm{H} \times \mathrm{Z}$ line $40 ; 41 ; 54 ; 61 ; 66 ; 71$ and 80 high tocopherol content was observed. Line $\mathrm{H} \times \mathrm{Z} 6 ; 11 ; 13 ; 15 ; 38 ; 50$ and 65 were characterized by a high phytosterol content. 


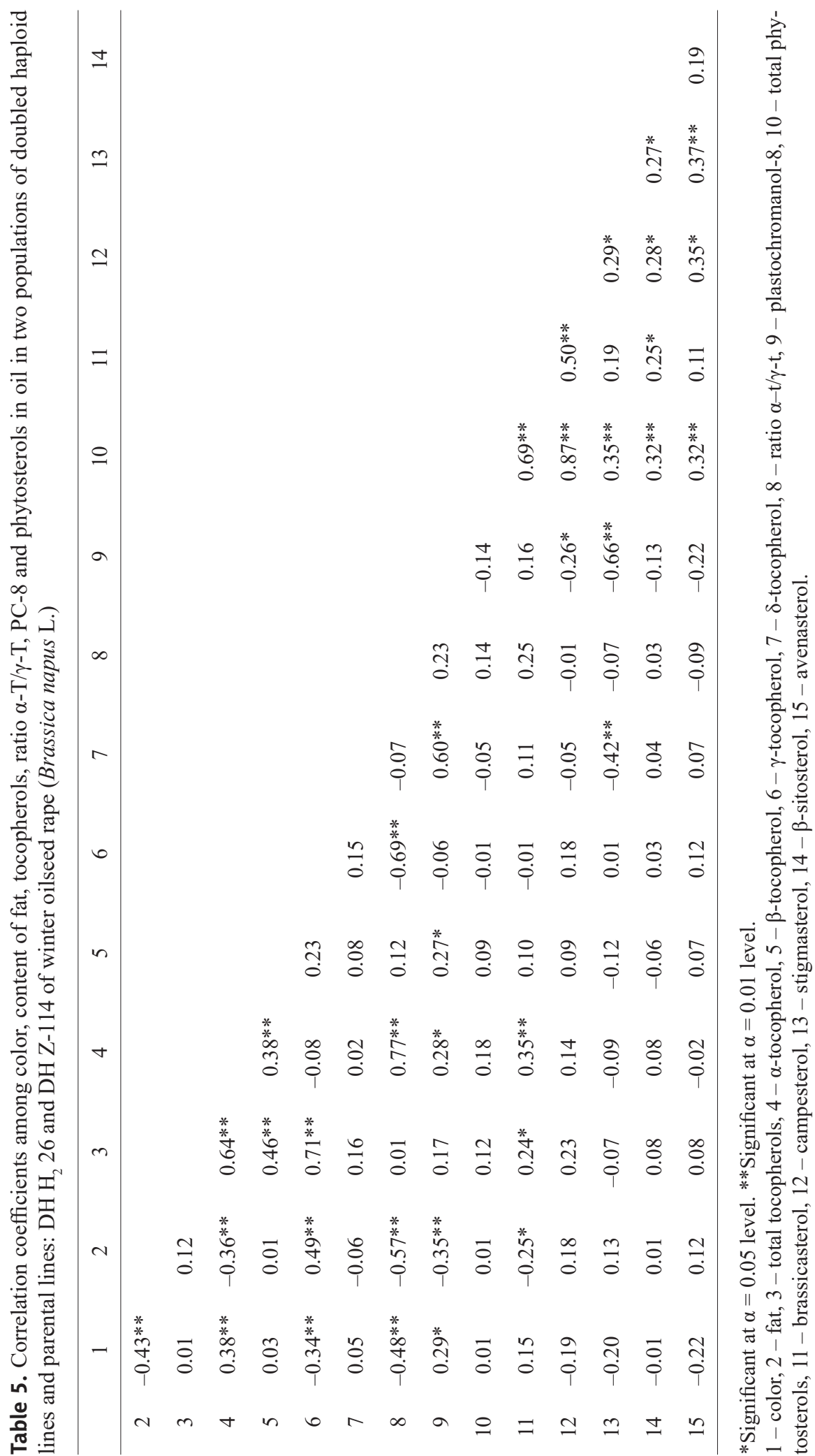



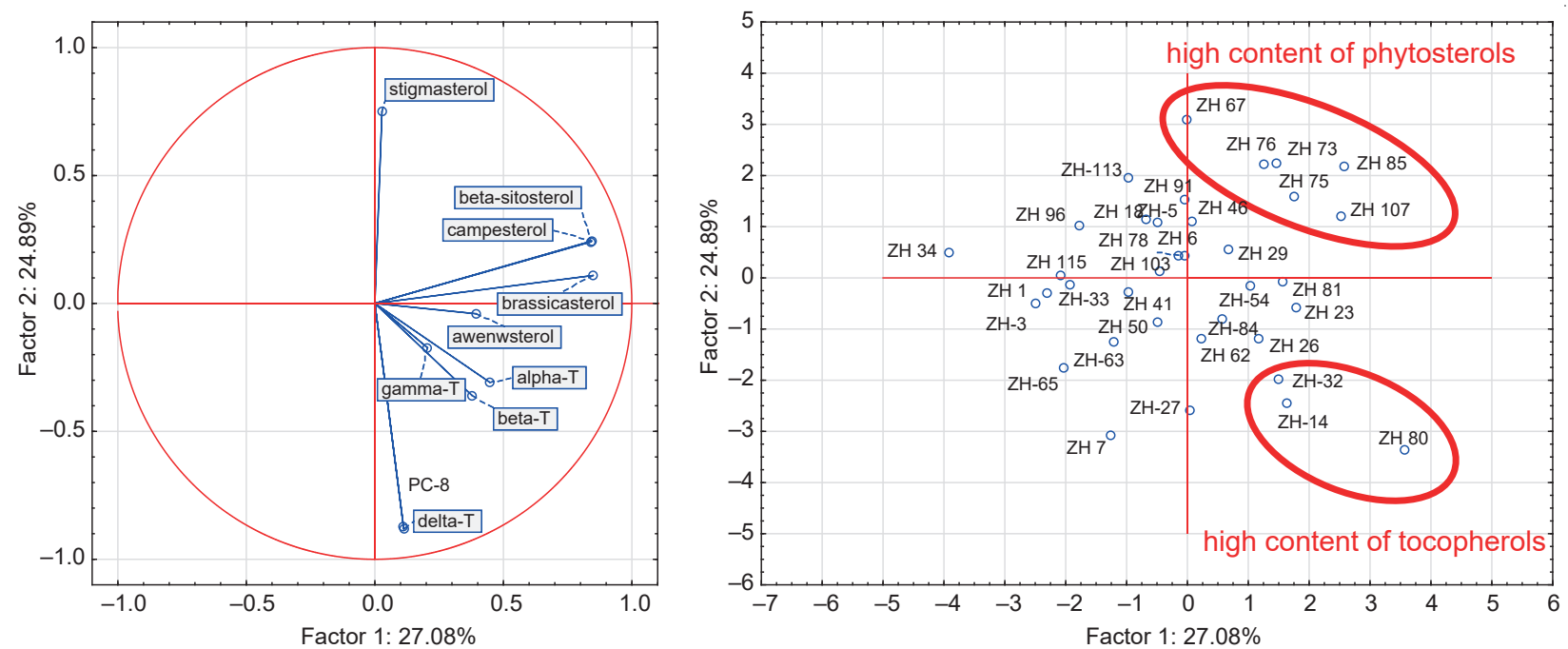

Fig. 2. A plot of two first principal components after PCA analysis of tocopherol and phytosterol contents in $\mathrm{Z} \times \mathrm{H}$ population of doubled haploid of winter oilseed rape (Brassica napus L.)
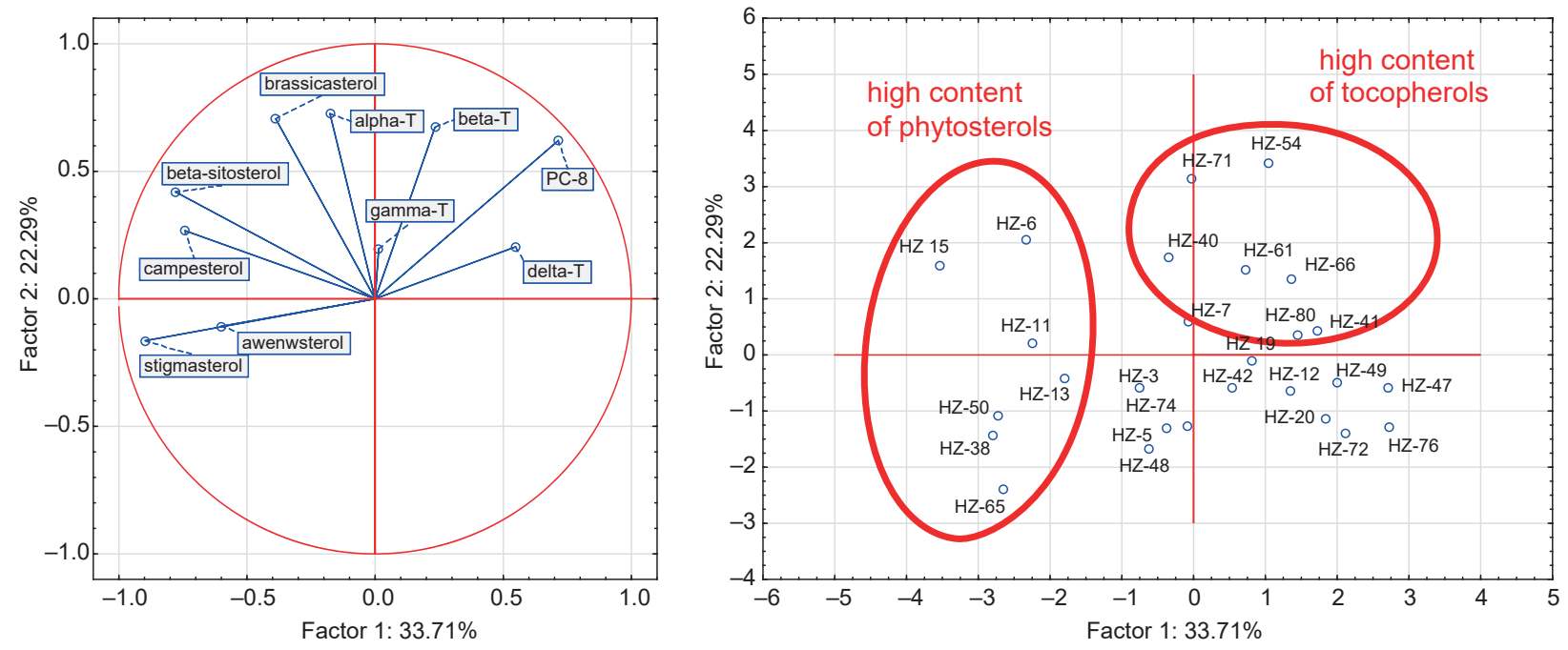

Fig. 3. A plot of two first principal components after PCA analysis of tocopherol and phytosterol contents in $\mathrm{H} \times \mathrm{Z}$ population of doubled haploid of winter oilseed rape (Brassica napus L.)

\section{CONCLUSIONS}

Considering the range of genetic variation among the doubled haploids of the two populations selected, DH lines may be good parents for further breeding programs focused on increasing the amount and improving the quality of oilseed rape oil. However, further studies will also be conducted to determine the influence of the environment on bioactive compounds in rapeseed oil. Cross direction of parental DH lines: yellow- and black-seeded has some influence, although not statistically significant, on the diversity of doubled haploid in their populations with regard to the level of average fat and tocochromanol and also phytosterol. 


\section{REFERENCES}

Abidi, S., List, G., Rennick, K. (1999). Effect of genetic modification on the distribution of minor constituents in canola oil. J. Am. Oil Chem. Soc., 76, 463-467.

Amar, S., Becker, H. C., Möllers, C. (2008a). Genetic variation and genotype $\times$ environment interactions of phytosterol content in three doubled haploid populations of winter rapeseed. Crop Sci., 48, 1000-1006.

Amar, S., Ecke, W., Becker, H. C., Möllers, C. (2008b). QTL for phytosterol and sinapate ester content in Brassica napus L. collocate with the two erucic acid genes. Theoret. Appl. Genet., 116, 1051-1061.

Blekas, G., Boskou, D. (1999). Phytosterols and stability of frying oils. In D. Boskou, J. Elmadfe (Eds), Frying of food (pp. 205-221). Lancaster-Basel: Technomic Publishing.

Booth, E., Gunstone, F. (2004). Rapeseeds and rapeseed oil: Agronomy, production, and trade. In F. D. Gunstone (Ed.), Rapeseed and canola oil production. Processing, properties and uses (pp. 1-16). Oxford, UK: Blackwell Publishers.

Cegielska-Taras, T., Tykarska, T., Szała, L., Kuraś, L., Krzymański, J. (2002). Direct plant development from microspore-derived embryos of winter oilseed rape Brassica napus L. ssp. oleifera (DC.) Metzger. Euphyt., 124, 341-347.

Ciftci, O. N., Przybylski, R., Rudzinska, M., Acharya, S. (2011). Characterization of fenugreek (Trigonella foenum-graecum) seed lipids. J. Am. Oil Chem. Soc., 88, $1603-1610$.

Dörmann, P. (2007). Functional diversity of tocochromanols in plants. Planta, 225, 269-276.

Eskin, N. (2013). Canola research: historical and recent aspects. In U. Thiyam-Holländer, N. A. Michael Eskin, B. Matthäus (Eds), Canola and rapeseed: Production, processing, food quality and nutrition. Boca Raton, FL, USA: CRC Press, Taylor and Francis Group.

Friedt, W., Snowdon, R. (2009). Oilseed rape. In Oil crops (pp. 91-126). Springer.

Fritsche, S., Wang, X., Li, J., Stich, B., Kopisch-Obuch, F. J., Endrigkeit, J., ..., Meng, J. (2012). A candidate gene-based association study of tocopherol content and composition in rapeseed (Brassica napus). The Brassica Genome, 84.

Gawrysiak-Witulska, M., Siger, A., Wawrzyniak, J., Nogala-Kalucka, M. (2011). Changes in tocochromanol content in seeds of Brassica napus L. during adverse conditions of storage. J. Am. Oil Chem. Soc., 88, 1379-1385.

Goffman, F. D., Becker, H. C. (2001). Diallel analysis for tocopherol contents in seeds of rapeseed. Crop Sci., 41, 1072-1079.

Goffman, F. D., Möllers, C. (2000). Changes in tocopherol and plastochromanol-8 contents in seeds and oil of oilseed rape (Brassica napus L.) during storage as influenced by temperature and air oxygen. J. Agric. Food Chem., 48, 1605-1609.

Gül, M. K., Amar, S. (2006). Sterols and the phytosterol content in oilseed rape (Brassica napus L.). J. Cell Mol. Biol., 5, 71-79.

Hamama, A. A., Bhardwaj, H. L., Starner, D. E. (2003). Genotype and growing location effects on phytosterols in canola oil. J. Am. Oil Chem. Soc., 80, 1121-1126.

Marwede, V., Gul, M., Becker, H., Ecke, W. (2005). Mapping of QTL controlling tocopherol content in winter oilseed rape. Plant Breed., 124, 20-26.

Marwede, V., Schierholt, A., Möllers, C., Becker, H. C. (2004). Genotype $\times$ environment interactions and heritability of tocopherol contents in canola. Crop Sci., 44, 728-731.

Matthäus, B. (2012). Oil technology. In Technological innovations in major world oil crops (Vol. 2, pp. 23-92). Springer.

Mène-Saffrané, L., DellaPenna, D. (2010). Biosynthesis, regulation and functions of tocochromanols in plants. Plant Phys. Biochem., 48, 301-309.

Meng, J., Shi, S., Gan, L., Li, Z., Qu, X. (1998). The production of yellow-seeded Brassica napus (AACC) through crossing interspecific hybrids of $B$. campestris (AA) and B. carinata (BBCC) with B. napus. Euphytica, 103, 329-333.

Michalski, K. (2009). Seed color assessment in rapeseed seeds using color and near infrared reflectance spectrometers. Rośl. Oleist., 30, 119-132.

Nogala-Kałucka, M., Muśnicki, C., Kupczyk, B., Jasińska-Stępniak, A., Bartkowiak-Fludra, E., Siger, A. (2005). Preliminary studies of tocochromanol content in seeds of open pollinated and hybrid varieties of winter rape. Rośl. Oleist.-Oilseed Crops, 26, 561-570.

Rahman, M., McVetty, P. (2011). A review of Brassica seed color. Can. J. Plant Sci., 91, 437-446.

Rashid, A., Rakow, G., Downey, R. (1994). Development of yellow seeded Brassica napus through interspecific crosses. Plant Breed., 112, 127-134.

Relf-Eckstein, J., Rakow, G., Raney, J. (2003). Yellowseeded Brassica napus - a new generation of high quality canola for Canada. Proceedings 11th International 
Rapeseed Congress (pp. 458-460). 6-10 July, Copenhagen, Denmark.

Siger, A., Michalak, M., Cegielska-Taras, T., Szała, L., Lembicz, J., Nogala-Kałucka, M. (2015). Genotype and environment effects on tocopherol and plastochromanol-8 contents of winter oilseed rape doubled haploid lines derived from F1 plants of the cross between yellow and black seeds. Ind. Crops Prod., 65, 134-141.

Wang, X., Zhang, C., Li, L., Fritsche, S., Endrigkeit, J., Zhang, W., ..., Meng, J. (2012). Unraveling the genetic basis of seed tocopherol content and composition in rapeseed (Brassica napus L.). Plos One, 7, e50038.

Wąsowicz, E., Rudzińska, M. (2010). Cholesterol and phytosterols. In Z. E. Sikorski, A. Kołakowska (Eds),
Chemical, biological, and functional aspects of food lipids (pp. 113-134). CRC Boca Raton: FL Press.

Wittkop, B., Snowdon, R., Friedt, W. (2009). Status and perspectives of breeding for enhanced yield and quality of oilseed crops for Europe. Euphytica, 170, 131-140.

Zhang, H., Shi, C., Wu, J., Ren, Y., Li, C., Zhang, D., Zhang, Y. (2004). Analysis of genetic and genotype $\times$ environment interaction effects from embryo, cytoplasm and maternal plant for oleic acid content of Brassica napus L. Plant Sci., 167, 43-48.

Zhao, J., Dimov, Z., Becker, H. C., Ecke, W., Möllers, C. (2008). Mapping QTL controlling fatty acid composition in a doubled haploid rapeseed population segregating for oil content. Molecular Breed., 21, 115-125. 